\title{
Zagrożenia osuwiskowe dla sztucznych zbiorników wodnych w Karpatach
}

\author{
Zbigniew Perski $^{1}$, Piotr Nescieruk ${ }^{1}$, Tomasz Wojciechowski ${ }^{1}$
}

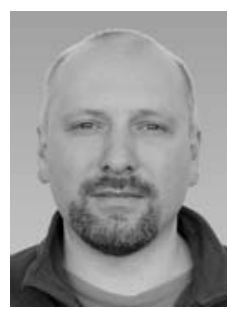

Z. Perski

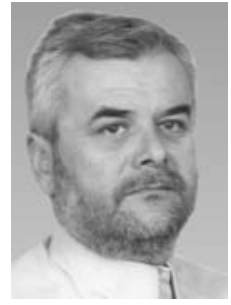

P. Nescieruk

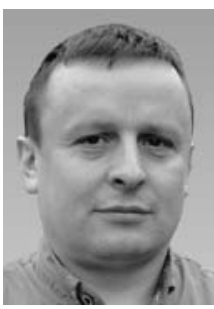

T. Wojciechowski

Landslide hazard to water reservoirs in the Carpathians. Prz. Geol., 67: 332-338; doi: 10.7306/2019.27

A b s tr a c t. Starting from 2011, landslides in Laski over the Żywieckie lake and in Piaski-Drużków over the Czchowskie Lake have been included into the landslide monitoring program as a part of the SOPO project of PGI-NRI. Both landslides present a real hazard to hydrotechnical constructions. In 2018 the monitoring has been extended for the Laski landslide including the on-line component. The article presents the subsurface and surface monitoring systems and discusses the results of over 7-years observations. In both discussed cases, the landslides have long, multi-stage history. The measurement data show that, their activity has decreased since the activation impulse in 2010. However, they remain active, especially on the deep slip surfaces. High porosity and, consequently, rapid changes in the groundwater level and rainfall intensity confirm the unstable nature of these landforms. This also confirms that the possibility of further activation or sudden landslide descent into water reservoirs is still a real hazard.

Keywords: geohazards, landslide monitoring, water reservoirs, Carpathians

Po katastrofalnych opadach deszczu, jakie nawiedziły południową część Polski na przełomie maja i czerwca 2010 r., w Karpatach odnotowano intensyfikację ruchów osuwiskowych, która przełożyła się na ogromną skalę zniszczeń. Jednym z osuwisk, które poczyniło znaczne szkody było osuwisko na terenie przysiąłka Łaski w Międzybrodziu Bialskim. Uszkodzonych lub całkowicie zdewastowanych zostało kilkadziesiąt budynków, linie przesyłowe i infrastruktura komunikacyjna. Ponieważ ogromne masy skalne przemieszczające się w dół stoku osuwały się do jeziora Międzybrodzkiego istniało zagrożenie, że przy stosunkowo szybkim ruchu powstanie fala, która może być dużym zagrożeniem zarówno dla samej zapory, jak i terenów położonych w dolnym odcinku doliny Soły (Nescieruk i in., 2013).

Bezpośrednie zagrożenie obiektów hydrotechnicznych wystapiło w tym samym czasie dla zespołu zbiorników wodnych Rożnów-Czchów w dorzeczu Dunajca. Największym problemem na tym obszarze było uaktywnienie się osuwiska na terenie przysiółka Piaski-Drużków, którego czoło schodzi do jeziora Czchowskiego w najbliższym sąsiedztwie zapory i tym samym może stanowić zagrożenie dla jej bezpieczeństwa (Wojciechowski i in., 2013a). Dla uproszczenia, w dalszej części tekstu osuwisko w przysiółku Łaski będzie nazywane osuwiskiem Łaski, a osuwisko w miejscowości Piaski-Drużków - osuwiskiem Piaski-Drużków.

\section{CHARAKTERYSTYKA OMAWIANYCH OSUWISK}

\section{Osuwisko Laski nad zbiornikiem Międzybrodzkim}

Osuwisko jest zlokalizowane w prawostronnej części jeziora Międzybrodzkiego, powyżej zapory w Porąbce w rejonie przysiółka Łaski (ryc. 1A, 2). Jest to osuwisko stare, które było aktywne w połowie ub.w. (Ziętara, 1968), a do roku 2010 było uważane za nieaktywne - ustabilizowane (Nescieruk, Wójcik, 1996). Osuwisko uaktywniło się w dn. 19 maja 2010 r., kiedy to intensywnymi ruchami została objęta prawie cała jego powierzchnia.

Osuwisko to można określić jako złożone (Bober i in., 1997), ze zróżnicowanymi strefami aktywności i różnymi sposobami i mechanizmami przemieszczeń w postaci świeżo występujących zsuwów oraz skarp wtórnych, szczególnie w pobliżu środkowej i dolnej części stoku osuwiskowego. Powierzchnia osuwiska w części górnej rozwinęła się w obrębie zwartego kompleksu leśnego, a środkowa i dolna część jest zurbanizowana. Osuwisko rozpoczyna się wyraźną skalną skarpą główną na wysokości 521 m n.p.m. o nachyleniu $35-40^{\circ}$, poniżej której znajduje się płytki rów rozpadlinowy, ograniczony od zachodu niskim wałem. W maju 2010 r. równolegle do skarpy głównej występowała otwarta szczelina o szerokości od kilku centymetrów do $2 \mathrm{~m}$ i głębokości 1-2 m, z wyraźnymi ślizgami w strefach powierzchni odkłucia, o upadzie ok. $75^{\circ}$. Od tego miejsca nastąpiło największe uaktywnienie w czerwcu 2010 r. Osuwisko schodzi w dół szeregiem aktywnych progów i skarp, którym towarzyszyły szczeliny rozciągające się przez całą szerokość osuwiska (Wieczorek i in., 2010).

W środkowej części, na wysokości ok. 500 m n.p.m. znajduje się stary (pierwotny) rów osuwiskowy, ograniczony od niższej części osuwiska, wyraźnym wałem. W tej części osuwiska były widoczne szczeliny i spękania, wzdłuż których miało miejsce intensywne przemieszczenie koluwiów. Poniżej - liczba spękań i szczelin oraz zniekształcenia powierzchni nasilały się. Świeże skarpy wewnątrzosuwiskowe miały wówczas wysokość nawet do $3 \mathrm{~m}$. W tej strefie uszkodzeniu uległy wszystkie budynki.

\footnotetext{
${ }^{1}$ Państwowy Instytut Geologiczny - Państwowy Instytut Badawczy, Centrum Geozagrożeń, ul. Skrzatów 1; 30-960 Kraków; zbigniew.perski@pgi.gov.pl; piotr.nescieruk@pgi.gov.pl; tomasz.wojciechowski@pgi.gov.pl
} 


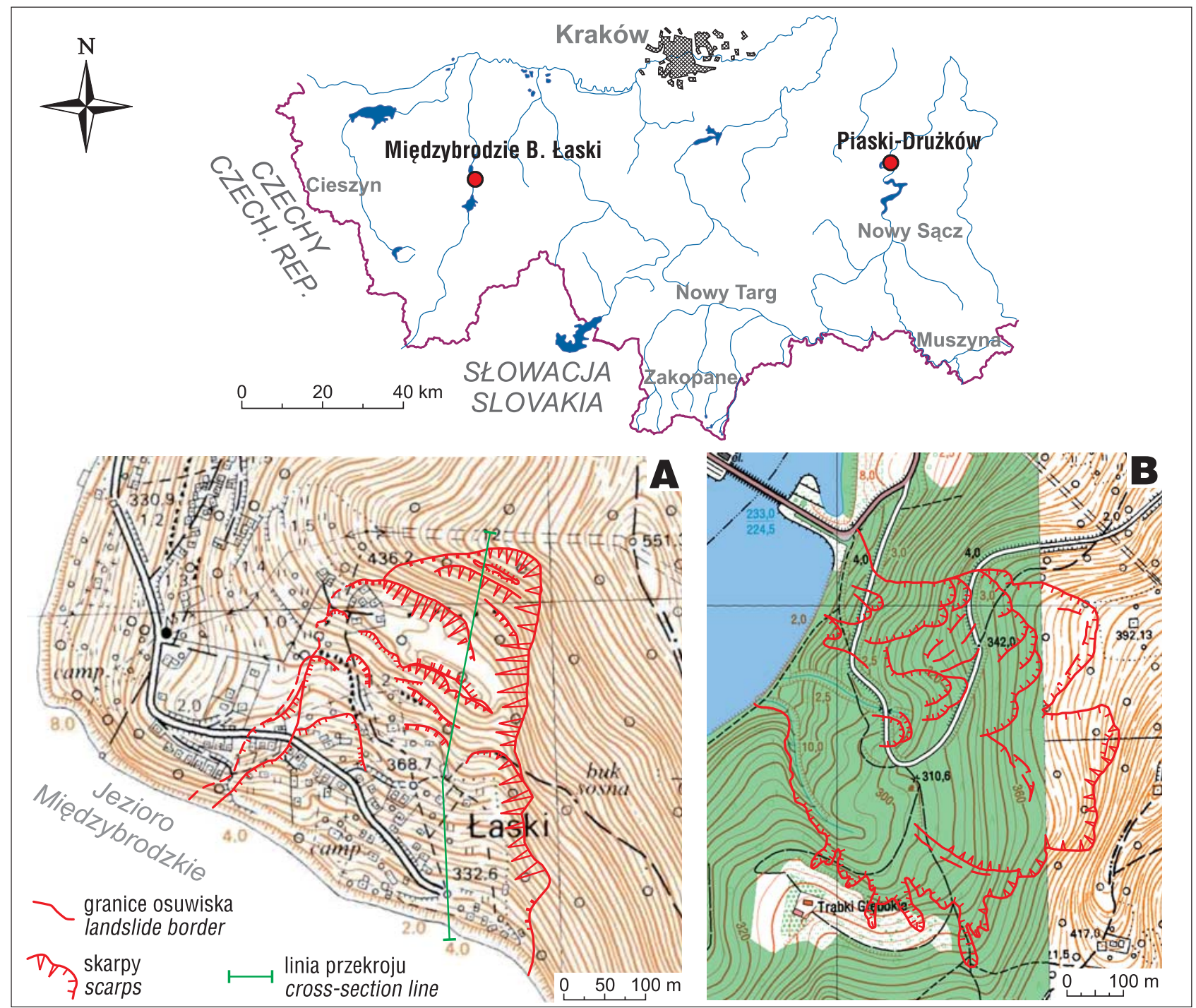

Ryc. 1. Szkice osuwisk Łaski (A) i Piaski-Drużków (B)

Fig. 1. Sketch maps of the Łaski landslide (A) and the Piaski-Drużków landslide (B)

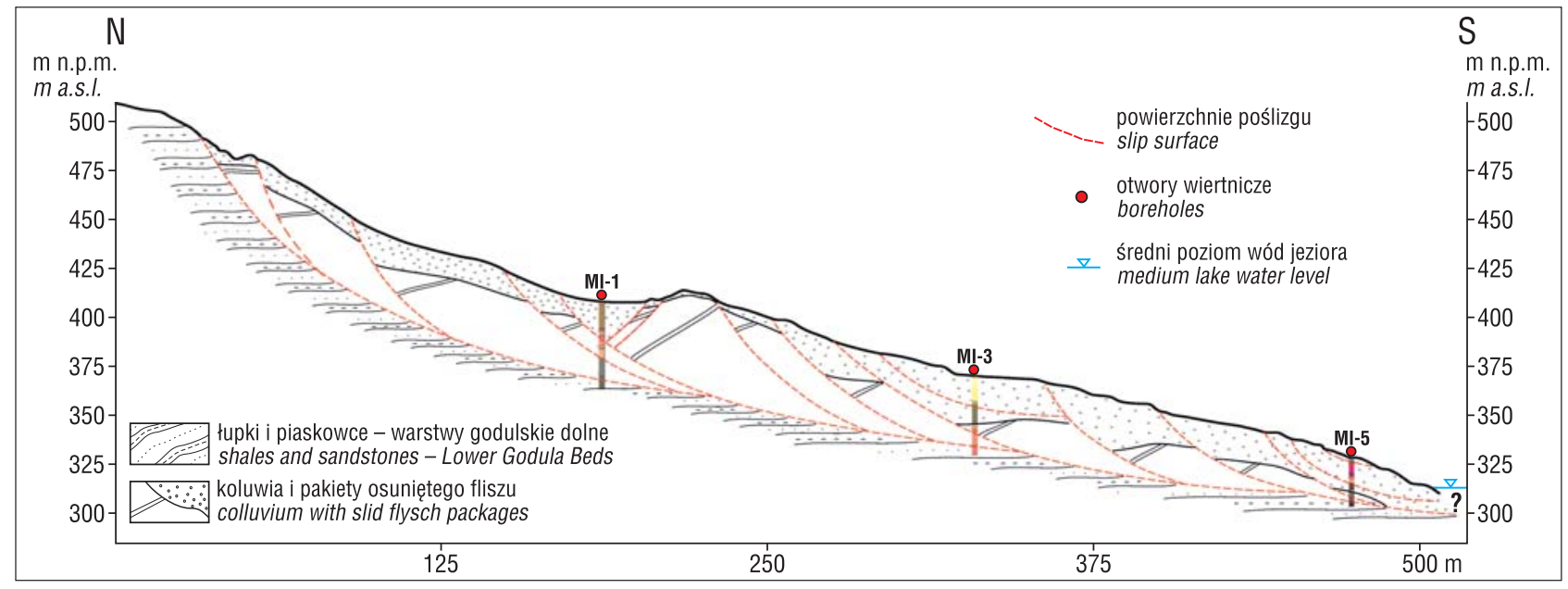

Ryc. 2. Przekrój przez osuwisko Łaski

Fig. 2. Cross section through the Łaski landslide

Na podstawie obserwacji terenowych i dotychczasowych badań (wiertniczych i geofizycznych) ustalono, że osuwisko jest rozwinięte w górnokredowych kompleksach piaskowcowo-łupkowych warstw godulskich. Jęzor osuwiska schodzi poniżej poziomu wody zbiornika Między- brodzkiego. Główna powierzchnia poślizgu jest rozwinięta na głębokości ok. $41 \mathrm{~m}$ p.p.t., a w obrębie badanego osuwiska występuje jeszcze kilka aktywnych płaszczyzn poślizgu. 


\section{Osuwisko Piaski-Drużków nad zbiornikiem Czchowskim}

Opisywane osuwisko obejmuje obszar 32,5 ha. Jego długość wynosi 660 m, natomiast szerokość 690 m, deniwelacja obszaru osuwiska - 192 m, a średnie nachylenie $16^{\circ}$. Sklasyfikowano je jako złożone, gdzie w dolnej części dominuje typ osuwiska obsekwentnego, natomiast w górnej jego części - konsekwentnego (ryc. 1B). Powstało najprawdopodobniej kilka tysięcy lat temu, rozwijając się na łupkowo-piaskowcowych pakietach warstw istebniańskich, a obecny kształt i morfologię uzyskało w kilku etapach rozwoju (Wójcik, 2011).

Osuwisko w części północno-wschodniej rozpoczyna się wyraźną świeżą skarpą przebiegającą w terenie zalesionym. Wyraźne ślady aktywności występują bezpośrednio poniżej skarpy, gdzie znajduje się świeży rów z rozciągania o szerokości do $20 \mathrm{~m}$. Jest to szacowana minimalna wartość przemieszczenia koluwiów osuwiskowych w górnej części. Współczesne ślady szczelin o prawie pionowym przebiegu pokazują, że powierzchnia poślizgu przebiega na znacznej głębokości. Szerokość świeżego i aktywnego rowu w części wschodniej osuwiska jest zmienna i wynosi od $5 \mathrm{~m}$ do ponad $30 \mathrm{~m}$. Tak też określono wielkość wektora poziomego przemieszczenia dla tej części osuwiska. Rów ten ma tendencję zarówno do poszerzania, jak i pogłębiania. Poniżej rowu powierzchnia terenu jest nierówna, występują wyraźne, świeże skarpy i szczeliny oraz nabrzmienia na powierzchni stoku. Ślady przemieszczeń zaobserwowano także na drodze leśnej w środkowej części osuwiska oraz poniżej tej drogi. Jak wynika z wieloletnich obserwacji, jest to najbardziej aktywny obszar. Te elementy wskazują, że przemieszczenia oprócz znacznej rozległości są też głębokie i mogą sięgać co najmniej poziomu brzegów Jeziora Czchowskiego (Wójcik i in., 2011).

Dużą aktywność osuwisko to wykazuje w części południowo-wschodniej, gdzie występują aktywne skarpy o wysokości 3 do $5 \mathrm{~m}$, rozwinięte w obrębie starszych form o wysokości 12 do 18 m. Poniżej skarp występują blokowiska i głazowiska oraz zagłębienia i rowy bezodpływowe. W tym obszarze zniszczeniu uległa znaczna część drzewostanu leśnego. Wielkość przemieszczeń poziomych jest tu szacowana na co najmniej $10 \mathrm{~m}$, ale może wynieść też znacznie więcej. Przemieszczenia pionowe (obniżanie) poniżej skarpy głównej w ciągu tylko ostatnich 10 miesięcy 2011 r. oszacowano na ok. $5 \mathrm{~m}$. W środkowej części osuwiska w obrębie niektórych pakietów skalnych stwierdzono podnoszenie, co wskazuje na złożony charakter przemieszczeń grawitacyjnych. W tych miejscach występują świeże zagłębienia bezodpływowe, niektóre $\mathrm{z}$ nich wypełnione były wodą (okresowe zbiorniki wód powierzchniowych stawy, jeziorka).

\section{SYSTEM MONITORINGU OMAWIANYCH OSUWISK}

Na obu omawianych osuwiskach zainstalowano odpowiednią infrastrukturę do monitorowania ruchów powierzchniowych jak i wgłębnych.

\section{Monitoring powierzchniowy}

Monitoring powierzchniowy oparto na metodach naziemnego skaningu laserowego i pomiarach GNSS.
Pomiary GNSS wykonywano na podstawie zastabilizowanych punktów pomiarowych zlokalizowanych w miejscach kluczowych z uwagi na dynamikę ruchów. Dla osuwiska Łaski było to 14 punktów, dla osuwiska Piaski-Drużków 13 punktów.

Jeśli chodzi o skaning laserowy, to w 2011 r. dla każdego z osuwisk wykonano tzw. skanowanie inwentaryzacyjne (Perski i in., 2012), którego celem było pozyskanie dokładnego numerycznego modelu powierzchni terenu osuwiska. Skanowanie to wykonano z wielu stanowisk rozmieszczonych na powierzchni osuwiska. W obu przypadkach nie udało się jednak uzyskać 100\% pokrycia powierzchni z uwagi na zalesienie i brak dostępności niektórych rejonów (szczeliny, głazowiska, powalone drzewa). Oprócz inwentaryzacji, dla każdego z osuwisk wykonywano cykliczne skanowania tzw. monitoringowe, które ma na celu uzyskanie danych o przemieszczeniach powierzchni terenu w kluczowych miejscach i obiektów budowlanych. Skanowanie takie prowadzono $\mathrm{z}$ tych samych stanowisk na przeciwległym brzegu jeziora. Dodatkowo przeprowadzono skanowania monitoringowe zakrętu drogi leśnej w środkowej części osuwiska, gdzie obserwowano największe przemieszczenia. Z uwagi na rozwijającą się roślinność i przebudowę drogi leśnej, monitorowania skanerem laserowym osuwiska Piaski-Drużków zaniechano jesienią 2015 r. Osuwisko Łaski jest nadal monitorowane skanerem naziemnym 2 razy do roku za pomocą pojedynczego skanu z przeciwległego brzegu. Warto zaznaczyć, że w analizach deformacji powierzchni terenu zaczęto wykorzystywać również dane laserowe pochodzące $\mathrm{z}$ lotniczego skaningu laserowego (Borkowski i in., 2011). Obydwa osuwiska zostały zmierzone tą metodą $w$ ramach projektu ISOK (Informatyczny System Osłony Kraju), a osuwisko Piaski-Drużków znajduje się w obszarze, na którym jest obecnie wykonywany powtarzalny lotniczy skaning laserowy w ramach projektu SOPO.

\section{Objętość koluwiów}

Przeprowadzone analizy materiałów archiwalnych, wyników prac wiertniczych, geofizycznych i geodezyjnych pozwoliły na oszacowanie objętości utworów koluwialnych uruchomionych w przypadku obu analizowanych osuwisk. W chwili obecnej w Łaskach na stoku znajduje się ok. $4109300 \mathrm{~m}^{3}$ materiału oderwanego od podłoża, co stanowi 78\% koluwiów (ryc. 3A). Pozostałe 28\% (ok. $1583200 \mathrm{~m}^{3}$ ) to materiał zdeponowany poniżej poziomu Jeziora Międzybrodzkiego. Maksymalną miąższość koluwium, wyznaczoną na podstawie analizy rdzeni, określono na głębokość ok. 47 m (Wojciechowski i in., 2013b).

W obrębie osuwiska Piaski-Drużków zostało uruchomione ok. $9 \mathrm{mln} \mathrm{m}^{3}$ materiału skalnego (ryc. 3B). Obecna objętość koluwium znajdująca się na stoku wynosi ok. $6,8 \mathrm{mln} \mathrm{m}^{3}$, co stanowi $75,5 \%$ objętości całego osuwiska (Wojciechowski i in., 2013a). Wynika z tego, że blisko 2,2 $\mathrm{mln} \mathrm{m}^{3}$ skał pochodzących z obszaru osuwiska zostało zerodowanych przez rzekę Dunajec i zapewne częściowo wybranych w okresie budowy sztucznego zbiornika wodnego. Część koluwium znajduje się nadal pod woda, zwłaszcza, że powierzchnia odkłucia w dolnej części jest zlokalizowana ok. $10 \mathrm{~m}$ poniżej średniego poziomu piętrzenia jeziora. Obecnie miąższość koluwium odwiercona w centralnej części osuwiska osiąga wartość 44,5 m. 


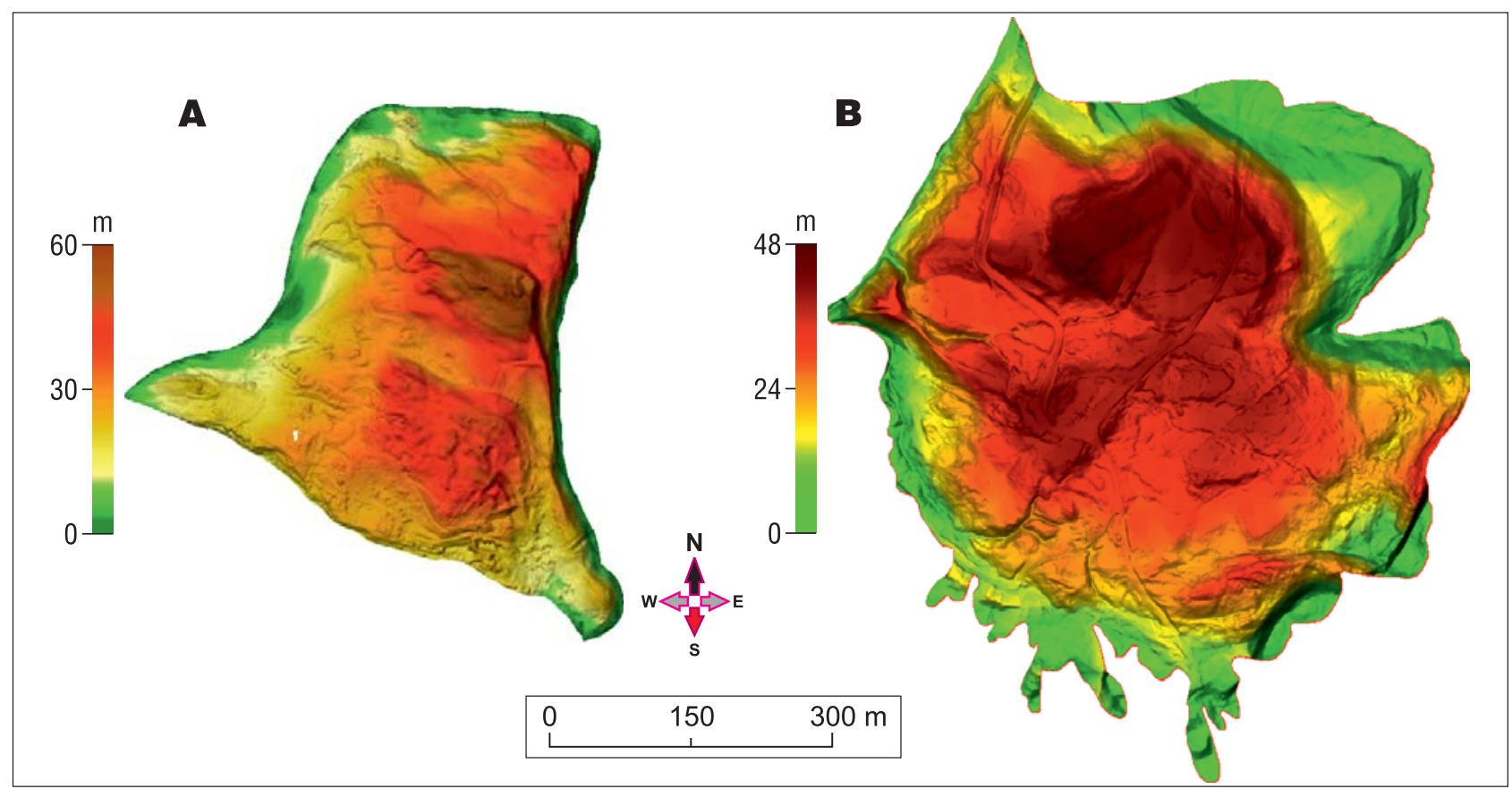

Ryc. 3. Mapy miąższości koluwiów osuwisk Łaski (A), Piaski-Drużków (B)

Fig. 3. Colluvium thickness map of the Łaski landslide (A) and the Piaski-Drużków landslide (B)

\section{Monitoring wgłębny i opadowy}

Celem pomiarów inklinometrycznych jest stwierdzenie, w jakim stopniu badany teren podlega deformacjom wgłębnym, a w szczególności określenie wielkości i prędkości przemieszczeń oraz wyznaczenie głębokości ich występowania. Pomiary są wykonywane sondą inklinometryczną (w tym przypadku Digital Inclinometer, RST) w przygotowanych otworach pomiarowych uzbrojonych rurami inklinometrycznymi. Zestaw ten umożliwia pomiar nachylenia kolumny w dowolnym punkcie na całej głębokości otworu z dokładnością 10-7 m. Przemieszczenia utworów koluwialnych mogą następować w różnych kierunkach. Aby wyniki kolejnych serii pomiarowych były porównywalne, orientacja sondy jest stała, gdyż przesuwa się ona w rowkach wyciętych w kolumnie.

$\mathrm{Na}$ obszarze omawianych osuwisk wykonano pary otworów badawczo-pomiarowych (inklinometr i piezometr, dla określania zmian poziomu wód gruntowych w czasie). $\mathrm{W}$ trakcie wiercenia otwory były pełnordzeniowane w celu uzyskania jak najdokładniejszych danych co do wykształcenia litologicznego koluwiów oraz przebiegu powierzchni poślizgu. Na obszarze osuwiska Łaski zlokalizowano 5 par otworów, a na Piaski-Drużków - 4 pary. Monitoring inklinometryczny jest prowadzony na obu osuwiskach od lata 2011 r. (pomiar bazowy), a do dzisiaj zrealizowano 19 sesji pomiarowych (wiosna/jesień).

W celu ustalenia, jaka jest zależność pomiędzy opadem atmosferycznym a zmianami zwierciadła wód gruntowych na osuwiskach zbiera się również dane opadowe, najczęściej w bezpośrednim ich sąsiedztwie. Na osuwiskach zainstalowano deszczomierze pomiarowe (Aster TPG-126), zsynchronizowane w zapisie godzinowym z urządzeniami rejestrującymi poziom wód gruntowych (Keller DCX-22AA) w otworach piezometrycznych.

\section{Monitoring online}

Od jesieni 2018 r. na osuwisku w Łaskach rozszerzono system monitoringu o komponent online. W 5 otworach piezometrycznych zamontowano urządzenia pomiarowe (Keller PA-26) z modułem zdalnej transmisji danych GSM-2. Wymieniono klasyczny deszczomierz na znormalizowaną stację meteorologiczną z zestawem czujników wykonujących pomiary: temperatury, wilgotności, opadów atmosferycznych, prędkości i kierunku wiatru. Dane pomiarowe są wysyłane przez sieć komórkową GSM/GPRS do serwera systemu, gdzie są gromadzone i udostępniane. Dodatkowo podczas odtwarzania i pogłębiania otworów zamontowano w nich system pomiaru TDR, który pozwoli na dalsze obserwacje wgłębne w razie zaciśnięcia bądź zerwania kolumn inklinometrycznych. W obrębie osuwiska zamontowano równocześnie 4-modułowy system pomiaru przemieszczeń (ekstensometryczny) wraz z trójstopniowym zestawem do pomiarów ciśnienia porowego. System ten jest zintegrowany $z$ rejestratorem danych i modułem bezpośredniej transmisji danych pomiarowych GSM/GPRS. Ostatnim elementem ciągłego systemu obserwacyjnego na osuwisku Łaski był montaż 2 zestawów pomiarowych GNSS (stacji referencyjnych) z modułami transmisji danych, umożliwiających zaawansowane monitorowanie przemieszczeń gruntu.

Każda z wymienionych powyżej części pomiarowych posiada system niezależnego zasilania oparty na akumulatorach i bateriach słonecznych, gwarantujący ciągłą pracę urządzeń niezależnie od warunków pogodowych. 
Cały system jest obecnie na etapie testowania i kalibracji, a jego pełne uruchomienie przewiduje się w czerwcu $2019 \mathrm{r}$.

\section{ANALIZA PRZEMIESZCZEŃ}

\section{Przemieszczenia powierzchniowe}

Analiza danych $\mathrm{z}$ monitoringu powierzchniowego pozyskanego punktowo za pomocą odbiorników GNSS oraz naziemnego skaningu laserowego wskazuje, że obydwa analizowane osuwiska wykazują obecnie aktywność tylko lokalnie w poszczególnych strefach. Po katastrofalnym osunięciu obydwu osuwisk w 2010 r. aktywnością charakteryzowały się całe ich powierzchnie. Prowadzone od 2011 r. pomiary powierzchniowe wskazują, że ich dynamika systematycznie malała, osiaggając stan pozornej równowagi w 2014 r. Od roku 2014 przemieszczenia poziome notowano tylko w określonych strefach osuwisk. Osuwisko Łaski jeszcze w 2013 r. było aktywne głównie w części środkowej, w strefie kumulacji materiału koluwialnego oddzielonego od skarpy głównej rowem rozpadlinowym. Przemieszczenia poziome osiągały $0,5 \mathrm{~m} / \mathrm{rok}$ (ryc. 4). Po tym okresie deformacje pojedynczych punktów osiągały wartości najwyżej $4 \mathrm{~cm} /$ rok tylko w centralnej i dolnej części osuwiska. Raport z monitoringu tego osuwiska w 2018 r. wskazuje, że powierzchnia terenu wykazuje

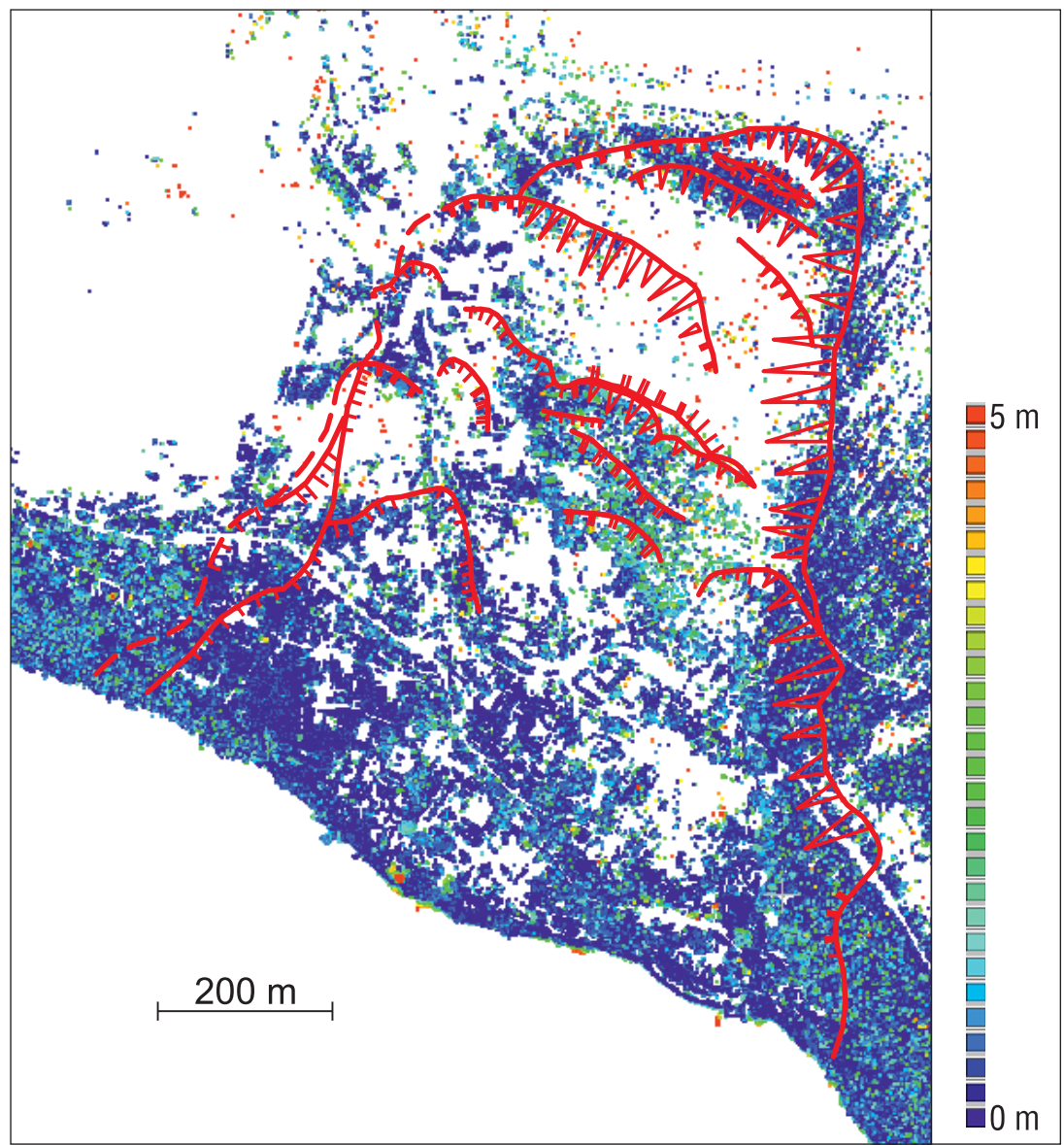

Ryc. 4. Przemieszczenia poziome na podstawie danych różnicowych z naziemnego skaningu laserowego pomiędzy pomiarami wykonanymi 06.03.2013 i 07.03.2012 r. Fig. 4. Horizontal displacement based on differential laser scanning data acquired on 06.03.2013 and 07.03.2012 aktywność tylko w jednym punkcie, w dolnej części osuwiska, i wynosi ona $7 \mathrm{~cm} / \mathrm{rok}$.

Osuwisko Piaski-Drużków również miało coraz mniejszą dynamikę, która w 2014 r. osiągała w poszczególnych punktach pomiarowych przesunięcia pionowe o wartości $22 \mathrm{~cm} /$ rok. Charakterystyczne dla tego osuwiska jest odmłodzenie w centralnej jego części, które miało miejsce w pierwszym kwartale 2013 r. Uaktywnienie zerwało całkowicie kilkudziesięciometrowy fragment drogi leśnej. Pomiary GNSS wykazały przemieszczenia poziome rzędu 3,62 m i pionowe osiagające 0,94 m (ryc. 5A). Deformacja ta została również ujęta $\mathrm{W}$ analizie danych $\mathrm{z}$ naziemnego skaningu laserowego (ryc. 5B) i wyraźnie zaznacza się w modelu różnicowym pomiędzy pomiarami lotniczymi wykonanymi w 2011 i 2018 r. (ryc. 5C). Raport z monitoringu powierzchniowego z $2018 \mathrm{r}$. wskazuje na dalszą aktywność osuwiska $\mathrm{w}$ tym rejonie. Przemieszczenia punktów pomiarowych dochodzą nawet do $10 \mathrm{~cm} / \mathrm{rok}$.

\section{Przemieszczenia wgłębne}

Na osuwisku Łaski na podstawie analizy danych wiertniczych wyznaczono od kilku do kilkunastu powierzchni poślizgu (ryc. 2). Z danych uzyskanych na podstawie pomiarów inklinometrycznych wynika, że jedynie kilka z nich wykazuje aktywność w całym okresie prowadzenia obserwacji (2011-2018). Dynamika na poszczególnych powierzchniach poślizgu jest silnie zróżnicowana, co dokumentuje złożoność ruchu mas koluwialnych, w tym rotacyjny charakter przemieszczeń. Największe przyrosty przemieszczeń występują na głębokościach 9,0-11,5 m p.p.t., osiągając maksymalne wartości do $20 \mathrm{~mm}$ pomiędzy cyklami pomiarowymi. Największe skumulowane wartości przemieszczeń od początku pomiarów osiagają 54-97 mm zarówno w płytszych (ok. 6 m p.p.t.), jak i głębszych (18-29 m p.p.t.) powierzchniach poślizgu. $\mathrm{Z}$ wykonanych pomiarów wynika, że średnie przemieszczenia wgłębne wynoszą ok. $14 \mathrm{~mm}$ rocznie. Odmienna sytuacja występowała jedynie w bocznej (wschodniej) części osuwiska, gdzie po 18 miesiącach doszło do całkowitego ścięcia kolumny pomiarowej na gł. 27,0 m p.p.t., po osiągnięciu przemieszczenia skumulowanego o wartość $450 \mathrm{~mm}$. Otwór ten odtworzono w $2017 \mathrm{r}$.

Szczególnie niebezpiecznym wydaje się fakt obserwowanej aktywności na najgłębszej strefie poślizgu, tj. na głębokości 41,5 i 40,0 m p.p.t. (otw. MI-1 ryc. 2). Po połączeniu wyników pomiarów z lokalizacją tych otworów w górnej części osuwiska można wysnuć wniosek o braku stabilizacji mas koluwialnych osuwiska w Łaskach.

W obrębie osuwiska Piaski-Drużków zlokalizowano 4 pary otworów pomiarowych, w których współcześnie obserwuje 

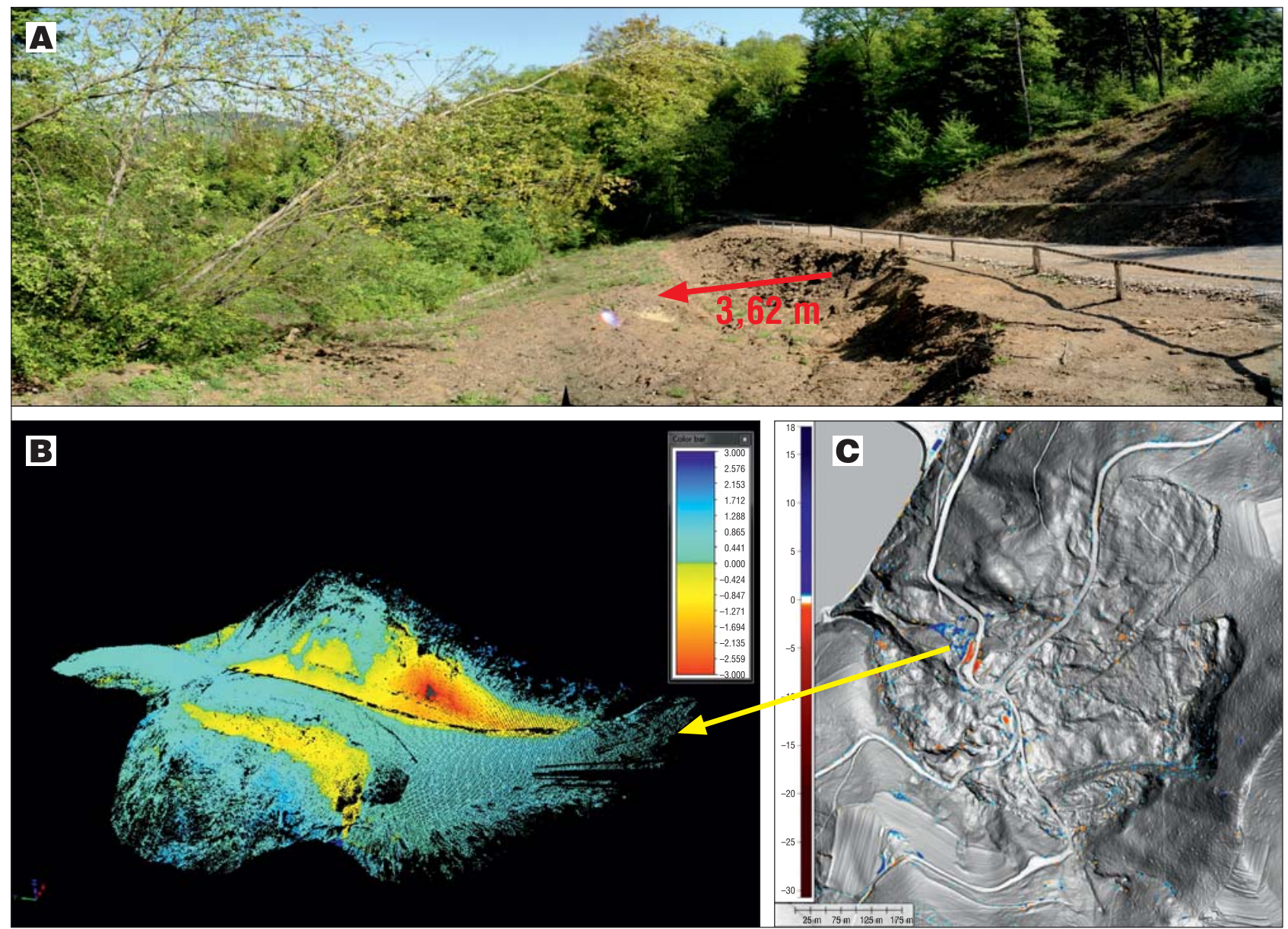

Ryc. 5. Przemieszczenia powierzchni terenu osuwiska Piaski-Drużków. A - przemieszczenie poziome punktu pomiarowego w 2013 r., B - model różnicowy aktywnego fragmentu osuwiska na podstawie danych TLS pozyskanych w dn. 17.04.2012 i 07.05.2013 r. C - model różnicowy osuwiska na podstawie danych ALS pozyskanych w 2011 i $2018 \mathrm{r}$.

Fig. 5. Terrain surface displacements of the Piaski-Drużków landslide. A - horizontal displacements of benchmark noted in 2013; B - differential model of active part of the landslide based on TLS data acquired on 17.04.2012 and 07.05.2013. C-differential model of the whole landslide based on ALS data acquired in 2011 and 2018

się 3-4 powierzchnie poślizgu. Najgłębsza z nich występuje na głębokości 42,0 m p.p.t., pozostałe znajdują się $\mathrm{w}$ przedziałach 6-10 m i 16-28 m p.p.t. Od początku badań wartości wykazują niewielkie wzrosty przemieszczenia, które zawierają się w przedziale $0,8-4,4$ mm/rok w części północnej osuwiska (otw. PI-1 - ryc. 6) i 5-10 mm/rok w części południowej. Maksymalna wartość przemieszczenia skumulowanego w tej części mierzona w okresie ostatnich 3 lat przekroczyła $54 \mathrm{~mm}$ i występuje na głębokości ok. $7 \mathrm{~m}$. Podobnie jak na osuwisku w Łaskach, tu także obserwuje się niewielkie przyrosty na najgłębszych ( 40 m) strefach poślizgu.

System obserwacji hydrogeologicznej badanych obiektów jest prowadzony na podstawie pomiarów zwierciadła wody w otworach piezometrycznych wykonanych w bezpośrednim sąsiedztwie inklinometrów a zsynchronizowanych z deszczomierzami.

Skrajnie niejednorodna budowa geologiczna oraz silne spękanie miąższych pakietów łupkowych i piaskowcowo-łupkowych, powoduje ,przesycenie koluwium” wodą już w ciagu 6-8 godzin po impulsie opadowym wielkości nawet $8-10 \mathrm{~mm} /$ godzinę. Dodatkowo o silnej szczelinowatości kompleksu utworów koluwialnych na osuwisku w Łaskach świadczy odnotowywanie dobowych wahań po- ziomu wody zbiornika w Międzybrodziu związane z pracą elektrowni szczytowo-pompowej.

\section{PODSUMOWANIE}

Dotychczasowe prace przeprowadzone na osuwiskach w Międzybrodziu Bialskim - Łaskach oraz Piaskach-Drużków pozwalają na wstępne sformułowanie następujących tez: - osuwiska należy w całości traktować jako obszar aktywny, świadczą o tym: odnotowywane przemieszczenia w otworach inklinometrycznych, które osiagają nawet $450 \mathrm{~mm}$ w czasie 1,5 roku obserwacji;

- przemieszczenia są obserwowane we wszystkich otworach pomiarowych niezależnie od ich lokalizacji;

- odnotowany ruch występuje ze zróżnicowaną siłą na różnych płaszczyznach poślizgu, niejednokrotnie w obrębie jednego otworu;

- przemieszczenia powierzchniowe obserwowane w skaningu laserowym wynoszą średnio ok. $20 \mathrm{~mm}$ (max. $30 \mathrm{~cm}$ ) pomiędzy poszczególnymi sesjami pomiarowymi;

- obserwowane są nowopowstające szczeliny i rozwarcia zarówno w obrębie infrastruktury budowlanej, jak i gruncie. 


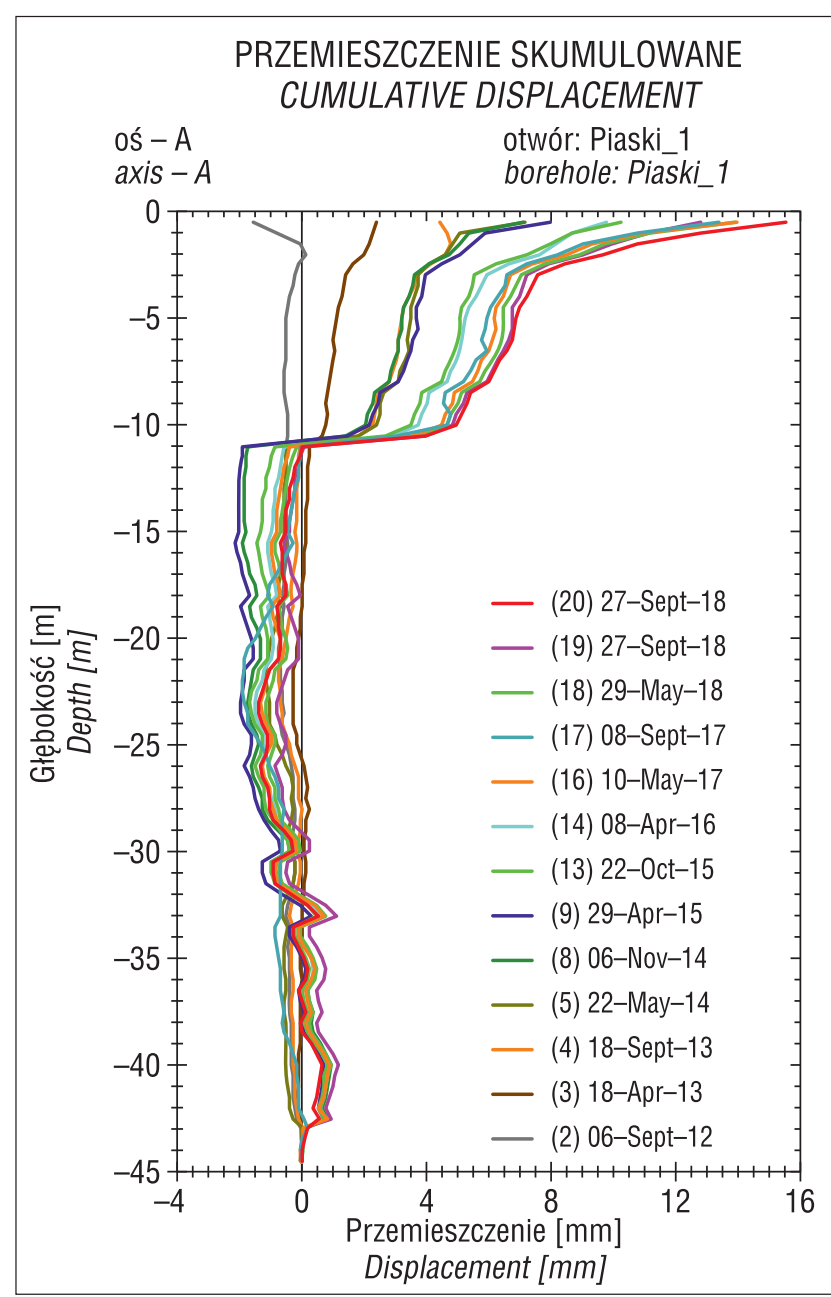

Ryc. 6. Wykres przemieszczenia skumulowanego na otworze PI-1 (Piaski-Drużków)

Fig. 6. Plot of cumulative displacement measured in borehole PI-1 (Piaski-Drużków)

Szczególne zagrożenie dalszego uaktywnienia obu osuwisk wynika z:

- głębokości zalegania aktywnych powierzchni poślizgu, odnotowywanych zarówno w badaniach geofizycznych jak i pomiarach inklinometrycznych, które sięgają powierzchni 41 metra p.p.t.,

- ilości powierzchni poślizgu obserwowanych w rdzeniach wiertniczych, które w razie wzmożonych opadów mogą się znacząco uaktywnić,

- silnej szczelinowatości masywu skalnego i utworów koluwialnych ułatwiających migrację wód opadowych,

- niejednorodności budowy geologicznej tego obszaru w tym znacznego udziału miąższych pakietów z dominacją łupków ilastych i mułowcowych.
Uwzględniając dotychczasowe wyniki badań i obserwacji, w tym wielkość i głębokość występowania przemieszczeń oraz czas, który minął od głównego epizodu osuwiskowego, należy stwierdzić, że brak jest możliwości naturalnego i pełnego ustabilizowania się tak rozległych obszarowo osuwisk. W obu przypadkach głównym czynnikiem wywołującym zmianę tempa przemieszczania się materiału koluwialnego, oprócz znacznego nachylenia stoków, jest jego szczelinowatość. Obszar opisywanych osuwisk w dalszym ciagu stwarza poważne zagrożenie, wzmożeniem swojej aktywności, dla istniejącej infrastruktury występującej w jego obrębie, jak również nagłego przemieszczenia materiału koluwialnego, które może doprowadzić do całkowitego zerwania i zsunięcia do sztucznych zbiorników wodnych.

\section{LITERATURA}

BOBER L., THIEL K., ZABUSKI L. 1997 - Zjawiska osuwiskowe w Polskich Karpatach Fliszowych. Geologiczno-inżynierskie właściwości wybranych osuwisk. Wyd. IBW PAN, Gdańsk.

BORKOWSKI A., PERSKI Z., WOJCIECHOWSKI T., JÓŹKÓW G., WÓJCIK A. 2011 - Landslides mapping in Roznow Lake vicinity, Poland using airborne laser scanning data. Acta Geodyn. Geomater., 163: 325-333.

NESCIERUK P., PERSKI Z., WOJCIECHOWSKI T., WÓJCIK A. 2013 - Osuwisko w Łaskach nad zbiornikiem w Porąbce jak przykład zagrożenia dla sztucznych zbiorników wodnych w Karpatach. Geotechnika. Nowoczesne rozwiazania konstrukcyjno-materiałowo-technologiczne. XXVIII Ogólnopolskie Warsztaty Pracy Projektanta Konstrukcji, Wisła, 5-8 marca 2013, 2: 1-10.

NESCIERUK P., WÓJCIK A. 1996 - Szczegółowa mapa geologiczna Polski w skali 1 : 50 000, ark. Bielsko-Biała (1012), wraz z objaśnieniami. Nar. Arch. Geol. PIG-PIB, Warszawa.

PERSKI Z., WOJCIECHOWSKI T., WÓJCIK A. 2012 - Techniki naziemne, lotnicze i satelitarne w rozpoznawaniu osuwisk. XIV Sympozjum Ogólnokrajowe Hydrotechnika: 57-69.

WIECZOREK D., WÓJCIK A., NESCIERUK P. 2010 - Karta dokumentacyjna osuwiska (numer ewidencyjny 2417022-5076). http://mapa.osuwiska.pgi.gov.pl (dostęp 19.02.2019).

WOJCIECHOWSKI T., WÓJCIK A., PERSKI Z., NESCIERUK P. 2013a - Zagrożenia osuwiskowe w strefach brzegowych zbiorników zaporowych Dunajca na przykładzie osuwiska w Czchowie. XV Sympozjum Ogólnokrajowe Hydrotechnika: 88-101.

WOJCIECHOWSKI T., NESCIERUK P., PERSKI Z., WÓJCIK A., WARMUZ B. 2013b - Wycieczka terenowa B-3: Aktywność osuwiska Łaski w Międzybrodziu Bialskim. LXXXII Zjazd Naukowy PTG „Wyzwania geologii regionu górnośląskiego w XXI wieku”, 19-21 IX $2013 \mathrm{r}$. Ustroń: $120-124$

WÓJCIK A. 2011 - Karta dokumentacyjna osuwiska wraz z opinią. Dotyczy osuwiska na wschód od zbiornika Czchowskiego. Nar. Arch. Geol. PIG-PIB, Kraków.

WÓJCIK A., NOWICKA D., PERSKI Z., WOJCIECHOWSKI T. 2011 Opinia geologiczna dotycząca obszaru i aktywności osuwiska powstałego w 2010 roku w rejonie zbiornika Czchowskiego i jego wpływu na prawe skrzydło zapory w Czchowie. Nar. Arch. Geol. PIG-PIB, Kraków: 31.

ZIĘTARA T. 1968 - Rola gwałtownych ulew i powodzi w modelowaniu rzeźby Beskidów. Pr. Geogr. IG PAN, 60: 1-116. 